\title{
Structural Characteristics of Mulato Grass I under Different Cutting Heights
}

\author{
Leonardo Assis Dutra1, Fabianno Cavalcante de Carvalho1, Eneas Reis Leite ${ }^{1 *}$, \\ Magno José Duarte Cândido², João Ambrósio de Araújo Filho1 \\ ${ }^{1}$ Curso de Zootecnia, Universidade Estadual Vale do Acaraú, Sobral, Brazil \\ ${ }^{2}$ Departamento de Zootecnia, Universidade Federal do Ceará, Fortaleza, Brazil \\ Email: ${ }^{*}$ eneas.leite@gmail.com
}

Received 14 January 2014; revised 15 February 2014; accepted 28 February 2014

Copyright (C) 2014 by authors and Scientific Research Publishing Inc.

This work is licensed under the Creative Commons Attribution International License (CC BY). http://creativecommons.org/licenses/by/4.0/

(c) (i) Open Access

\section{Abstract}

This work aimed to evaluate the effects of different individual heights of cut on structural characteristics of Brachiaria hibrida cv. Mulato I in four periods of the year. The study was carried out at the Fazenda Experimental Vale do Acaraú, in Sobral, Ceará, Brazil, from January to December, 2008. The experimental design was a split plot, with the plots representing four pasture conditions through manual cuts of $10 \mathrm{~cm}, 20 \mathrm{~cm}, 30 \mathrm{~cm}$ and $40 \mathrm{~cm}$ heights, which were done every 30 days. Each treatment had three replications. The subplots were represented by four periods of evaluation: January-February-March, April-May-June, July-August-September and October-November-December. Fertilization was performed with $350 \mathrm{~kg}$ of $\mathrm{N} / \mathrm{ha}$, divided into monthly applications. Irrigation was conducted in alternate days during the dry season. The variables studied were: mean height before cutting (cm); dry matter content (\%); total dry matter production (t/ha); percentage of leaves; percentage of stems; percentage of dead material; leaf blade/stem ratios; number of total leaves per tiller; number of live leaves per tiller; average size of leaves; and tiller density. Cutting at $10 \mathrm{~cm}$ caused a decrease in total dry matter production, underestimating the potential production. Cutting heights between 20 and $30 \mathrm{~cm}$ contributed positively to increase the total number of leaves, number of green leaves, average size of the leafs and total dry matter production. Under the present experimental conditions, cutting around $40 \mathrm{~cm}$ was not recommended because of a decreasing in the leaf/stem ratio and a increasing in stem fraction and dry matter content, compromising the structure of the canopy.

\section{Keywords}

Grazing Management; Leaf/Stem Ratio; Tillers

${ }^{*}$ Corresponding author. 


\section{Introduction}

Native pastures are the main sources of food for ruminants in Northeast Brazil. Considering that animal feeding represents $70 \%$ to $80 \%$ of total costs [1], it is justifiable to maximize the use of pastures. Their correct use allows the conversion of structural carbohydrates into proteins of high biological value at a relatively low cost.

Grasses from Brachiaria genus are the basis of animal production in the tropics, allowing extensive areas for livestock, including those being considered as marginal zones in the past doing to the low quality soils, which represent more than 40 million hectares in Brazil [2].

The morphogenic variables determine the structural characteristics of pastures, and the most important are the number and size of leaves and tiller density [3]. Besides defining the leaf area index in the pasture, the structural characteristics present high correlation with the intake variables [4], which constitute important factors for evaluation of pasture quality [5].

According to [6], the knowledge of morph physiological features of forage grasses represents the starting to the basic understanding of plant responses to cut or grazing. Therefore, it is indispensable a proper and deeper study on morphogenic and structural characteristics in integrated and differentiated manners for the main grasses of economic interest.

This work had it as objective to evaluate the effects of different heights of cuts, in four periods of the year, on structural characteristics of Brachiaria hibrida cv. Mulato I.

\section{Material and Methods}

The study was carried out at the Acaraú Valley Experiment Station, in Sobral, state of Ceará, Brazil, a physiographic zone known as "Sertão Cearense", located at $3^{\circ} 42^{\prime}$ South latitude, $40^{\circ} 21^{\prime}$ West longitude and altitude of $83 \mathrm{~m}$. The experimental period lasted 12 months, from January to December, 2008.

The soil in the experimental areas was aluvisoil ortocromic type, clayey texture, moderately drained and deep [7], hyperxerophytic "caatinga" phase, flat and soft wavy terrain. Fertilization used was equivalent to $350 \mathrm{~kg}$ of $\mathrm{N} / \mathrm{ha} / \mathrm{year}$, divided into monthly applications. Irrigation was used on alternate days during the dry period. The rainfall distribution during the experimental period is presented in Figure 1 . The temperature varied from $24^{\circ} \mathrm{C}$ to $36^{\circ} \mathrm{C}$ and relative humidity ranged from $55 \%$ to $68 \%$ during the period of study.

The experiment followed a split plot design, where the plots corresponded to four pasture conditions represented by heights of residues cuts of $10 \mathrm{~cm}, 20 \mathrm{~cm}, 30 \mathrm{~cm}$ and $40 \mathrm{~cm}$ after, which were conducted every 30-day. Each plot had three replications and the subplots were represented by four periods of evaluation consisting of quarterly averages (January-February-March, April-May-June, July-August-September and October-November- December). Thus, the test showed a total of 12 experimental units (4 treatments $\times 3$ replications) $\times 4$ periods, with a $2.0 \mathrm{~m} \times 2.0 \mathrm{~m}$ area per unit. The total experimental area comprised about $96 \mathrm{~m}^{2}$

The height of the pasture (treatments) was monitored through 20 readings by using a transparency, which was placed on the pasture and had its height above the ground measured with a ruler.

The evaluation of tiller density was performed independently of the demographic patterns of tillering. Iron frames of $1.00 \mathrm{~m} \times 0.25 \mathrm{~m}\left(0.25 \mathrm{~m}^{2}\right)$ were used, and one above ground sample per plot was collected. Were also collected 20 tillers per plot (cut at soil level) for determination of the average tiller weight? The material was placed in plastic bags and stored in a cold chamber for further lab processing.

The samples from sampling frames, as well as the samples of tillers, were weighed and sub samples of $50 \mathrm{~g}$ were separated from each frame. After counting the number of tillers by sub-sample, each one was separated into fractions: leaf blades, stems and dead material. These fractions were weighed and brought to a forced ventilation oven to dry at $65^{\circ} \mathrm{C}$ for 72 hours. After drying, the fractions were weighed and then calculated the dry matter content to determine dry matter production, the average weight of the tiller (harvested at ground level), percentages of leaf blade, stem and dead material, and the leaf blade/stems ratio.

Statistical analyzes were performed by using the general linear model procedure (GLM) and regression (REG) available in the Statistical Analysis System, version 8.9, considering as sources of variation the cutting heights and evaluation periods, which were analyzed by a F test at $5 \%$ probability. Since the height factor is quantitative, its effect was evaluated by regression analysis.

\section{Results and Discussion}

The average heights before cutting are shown in Table 1. It was observed that the interaction between residue 
height and periods of evaluation was not significant $(\mathrm{P}>0.05$ ). This effect can be justified by the use of irrigation throughout the experimental period, minimizing the effects of the dry season and the rainy season within the established periods.

In general it was observed an increasing in height before cutting with the increasing residue height after cutting. It was observed a linear effect $(\mathrm{P}<0.05)$ of residue heights over the heights before cutting, in the average of all studied periods, which is described by the equation $\mathrm{Y}$ mean $=1.019 \mathrm{x}+8.555\left(\mathrm{R}^{2}=99.64 \%\right)$.

In the $10 \mathrm{~cm}$ residue cut treatment it was observed an average growth of $9.66 \mathrm{~cm}$ every 30 days, whereas in the $40 \mathrm{~cm}$ treatment in the same period it was $12.09 \mathrm{~cm}$, showing a $20 \%$ growth. According to [8], forage plants cut to greater heights may retain larger amounts of photosynthetically active leaf tissues and may result in fewer cuts of apical meristems, becoming more vigorous during regrowth.

[9] pointed out that pasture height in pre-grazing as guide variable is useful to control grazing management in situations of intermittent defoliation if their values had been obtained from measurements of Leaf Area Index and the correspondents Light Trapping.

For dry matter content the interaction between the heights of residues and evaluation periods was not significant $(\mathrm{P}>0.05)$ (Table 2). However, significant differences $(\mathrm{P}<0.05)$ were found for periods, with the average from October to December showing the highest content of dry matter. Despite irrigation, the warmer and dryer weather in this period in the region possibly influenced this variable. In this context, [10] mentioned that the

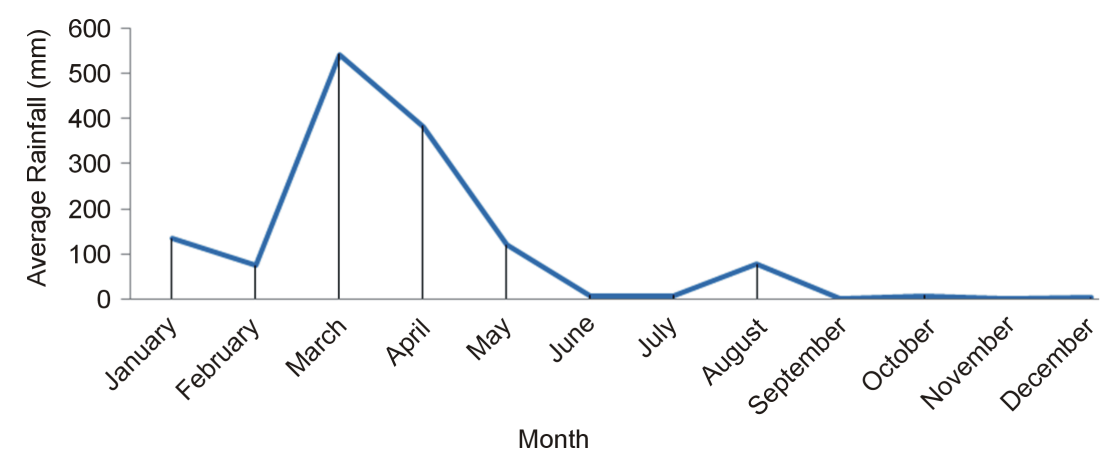

Figure 1. Distribution of rainfall during the experimental period.

Table 1. Average height before cutting $(\mathrm{cm})$ in pastures of Brachiaria hibrida cv. Mulato I under different cutting heights.

\begin{tabular}{|c|c|c|c|c|c|}
\hline \multirow{2}{*}{ Period of evaluation } & \multicolumn{4}{|c|}{ Heights of Residues (cm) } & \multirow{2}{*}{ Mean } \\
\hline & 10 & 20 & 30 & 40 & \\
\hline Jan-Mar & 19.35 & 31.65 & 47.83 & 58.05 & $39.22^{\mathrm{A}}$ \\
\hline Apr-Jun & 18.83 & 28.42 & 41.65 & 49.72 & $34.66^{\mathrm{B}}$ \\
\hline Jul-Sep & 22.42 & 31.61 & 45.81 & 56.05 & $38.97^{\mathrm{A}}$ \\
\hline Oct-Dec & 18.05 & 27.86 & 35.81 & 44.05 & $31.56^{\mathrm{B}}$ \\
\hline Mean & $19.66^{\mathrm{d}}$ & $29.88^{c}$ & $42.78^{\mathrm{b}}$ & $52.09^{\mathrm{a}}$ & \\
\hline
\end{tabular}

Coefficient of Variation $(\mathrm{CV})=9.50 \%$; Capital letters followed by the same letter in the column do not differ $(\mathrm{P}>0.05)$ by Tukey test. Tiny letters followed by the same letter in the line do not differ $(\mathrm{P}>0.05)$ by Tukey test.

Table 2. Average content (\%) of dry matter in pastures of Brachiaria hibrida cv. Mulato I under four cutting heights.

\begin{tabular}{|c|c|c|c|c|c|}
\hline \multirow{2}{*}{ Period of evaluation } & \multicolumn{4}{|c|}{ Heights of Residues (cm) } & \multirow{2}{*}{ Mean } \\
\hline & 10 & 20 & 30 & 40 & \\
\hline Jan-Mar & 24.59 & 26.86 & 28.64 & 27.32 & $26.85^{\mathrm{B}}$ \\
\hline Apr-Jun & 25.68 & 27.61 & 27.77 & 28.55 & $27.40^{\mathrm{B}}$ \\
\hline Jul-Sep & 25.31 & 27.66 & 29.55 & 29.63 & $28.04^{\mathrm{AB}}$ \\
\hline Oct-Dec & 30.39 & 31.93 & 31.35 & 31.19 & $31.22^{\mathrm{A}}$ \\
\hline Mean & $26.49^{\mathrm{a}}$ & $28.52^{\mathrm{a}}$ & $29.33^{\mathrm{a}}$ & $29.17^{\mathrm{a}}$ & \\
\hline
\end{tabular}

Coefficient of Variation $(\mathrm{CV})=3.19 \%$; Capital letters followed by the same letter in the column do not differ (P > 0.05) by Tukey test. Tiny letters followed by the same letter in the line do not differ $(\mathrm{P}>0.05)$ by Tukey test. 
highest values of cell wall constituents in the dry period support the effects, especially the high temperatures on forage composition.

The average contents of dry matter, as a function of residue heights after cuts, were adapted to the linear regression model $(\mathrm{P}<0.05)$ in the heights of residues tested as described by the equation $\mathrm{Y}$ mean $=0.0009 \mathrm{x}+$ $0.2617\left(\mathrm{R}^{2}=76.51 \%\right)$. As can be observed, the Mulato I grass increased its dry matter content as a function of residue heights. The dry matter content in forage plants is influenced by plant morphology and by genotype [11]. Thus, as the plant develops its morphology is altered, particularly by decreasing the leaf/stem ratio [12]. C4 grasses, which constitute the tropical grasslands, exhibit changes in their morphological and chemical characteristics, which are associated with development, physiological maturity and natural senescence, affecting quality and availability of forage as well as pasture structure, therefore influencing intake and animal performance [13].

There was an interaction between height of residues $\mathrm{x}$ evaluation periods $(\mathrm{P}<0.05)$ for total dry matter production (Table 3). The period from January to March showed the highest average for total dry matter production $(\mathrm{P}<0.05)$. This was due to the greater participation of the stems fraction during this period (Table 4). The increased production of forage mass was possibly a result of the adopted management practices and from the different rates of growth the plant can present in different seasons due to changes in environmental factors.

The positive linear model was the best fit $(\mathrm{P}<0.05)$ for average dry matter production as a function height of residues after cutting, which is described by the equation $Y$ mean $=0.2223 x+0.48\left(R^{2}=99.08 \%\right)$. Studies with grazing animal shave shown that lower heights reduce forage mass when continuous stockings [14] [15] or intermittent stockings [16] [17] are used.

According to [18], any effect on leaf elongation rate affects the speed of leaf emergence, as well as the emergence of tillers and the consequent production of total dry matter. Among these factors is the height of cut. In forage plants that grow as clumps cuts close to the ground can eliminate much of the leaf area, besides destroying large number of apical meristems, which will result in lower regrowth and production.

It was observed the interaction height of post-harvest residues $\mathrm{x}$ periods of evaluation $(\mathrm{P}<0.05)$ for percentage of leaves (Table 5). For averages in the periods was observed an increase $(\mathrm{P}<0.05)$ in participation of leaf blade fraction in the third and fourth evaluation periods, with higher values than the stem fractions. This increase occurred concomitantly with the decline in the total average production of dry matter and with the decreasing participation of tiller fractions in the same periods.

For the average of sheet fractions as a function of the height of residue after cutting, the regression showed a negative linear effect defined by the equation $\mathrm{Y}$ mean $=0.0062 \mathrm{x}+0.6335\left(\mathrm{R}^{2}=94.27 \%\right)$. Possibly the lowest

Table 3. Total dry matter production (t/ha) in pastures of Brachiaria hibrida cv. Mulato I under four cutting heights.

\begin{tabular}{cccccc}
\hline \multirow{2}{*}{ Periods of evaluation } & \multicolumn{2}{c}{ Heights of Residues (cm) } & Mean \\
\cline { 2 - 5 } Jan-Mar & 10 & 20 & 30 & 40 & $14.41^{\mathrm{Aa}}$ \\
Apr-Jun & $4.34^{\mathrm{Ac}}$ & $6.33^{\mathrm{Abc}}$ & $9.33^{\mathrm{Ab}}$ & $7.60^{\mathrm{A}}$ \\
Jul-Sep & $2.07^{\mathrm{Ac}}$ & $4.52^{\mathrm{Abc}}$ & $5.84^{\mathrm{Bab}}$ & $7.54^{\mathrm{Ba}}$ & $4.99^{\mathrm{B}}$ \\
Oct-Dec & $2.01^{\mathrm{Ac}}$ & $3.57^{\mathrm{Abc}}$ & $5.37^{\mathrm{Bab}}$ & $7.93^{\mathrm{Ba}}$ & $4.72^{\mathrm{B}}$ \\
Mean & $3.24^{\mathrm{Ac}}$ & $4.66^{\mathrm{Abc}}$ & $6.83^{\mathrm{ABab}}$ & $8.64^{\mathrm{Ba}}$ & $5.84^{\mathrm{B}}$ \\
\hline
\end{tabular}

Coefficient of Variation $(\mathrm{CV})=17.74 \%$; Capital letters followed by the same letter in the column do not differ $(\mathrm{P}>0.05)$ by Tukey test. Tiny letters followed by the same letter in the line do not differ $(\mathrm{P}>0.05)$ by Tukey test.

Table 4. Percentage of stems in pastures of Brachiaria hibrida cv. Mulato I under four cutting heights.

\begin{tabular}{|c|c|c|c|c|c|}
\hline \multirow{2}{*}{ Periods of evaluation } & \multicolumn{4}{|c|}{ Heights of Residues (cm) } & \multirow{2}{*}{ Mean } \\
\hline & 10 & 20 & 30 & 40 & \\
\hline Jan-Mar & 34.79 & 45.66 & 45.93 & 53.30 & $44.92^{\mathrm{A}}$ \\
\hline Apr-Jun & 27.24 & 36.31 & 43.44 & 46.71 & $38.43^{\mathrm{B}}$ \\
\hline Jul-Sep & 25.30 & 32.21 & 38.03 & 41.45 & $34.25^{\mathrm{B}}$ \\
\hline Oct-Dec & 32.52 & 36.22 & 38.43 & 44.12 & $37.82^{\mathrm{B}}$ \\
\hline Mean & $29.96^{\mathrm{c}}$ & $37.60^{\mathrm{b}}$ & $41.46^{\mathrm{ab}}$ & $46.40^{\mathrm{a}}$ & \\
\hline
\end{tabular}

Coefficient of Variation $(\mathrm{CV})=5.31 \%$; Capital letters followed by the same letter in the column do not differ $(\mathrm{P}>0.05)$ by Tukey test. Tiny letters followed by the same letter in the line do not differ $(\mathrm{P}>0.05)$ by Tukey test. 
Table 5. Percentage of leafs in pastures of Brachiaria hibrida cv. Mulato I under four cutting heights.

\begin{tabular}{|c|c|c|c|c|c|}
\hline \multirow{2}{*}{ Periods of evaluation } & \multicolumn{4}{|c|}{ Heights of Residues (cm) } & \multirow{2}{*}{ Mean } \\
\hline & 10 & 20 & 30 & 40 & \\
\hline Jan-Mar & $53.79^{\text {Аа }}$ & $38.34^{\mathrm{Bb}}$ & $35.47^{\mathrm{Bb}}$ & $33.27^{\mathrm{Bb}}$ & $40.22^{\mathrm{B}}$ \\
\hline Apr-Jun & $58.27^{\text {Aa }}$ & $52.07^{\mathrm{Aa}}$ & $41.34^{\mathrm{ABb}}$ & $41.23^{\mathrm{ABb}}$ & $48.23^{\mathrm{A}}$ \\
\hline Jul-Sep & $65.37^{\mathrm{Aa}}$ & $55.53^{\text {Aab }}$ & $46.47^{\mathrm{Abc}}$ & $41.40^{\mathrm{Abc}}$ & $52.19^{\mathrm{A}}$ \\
\hline Oct-Dec & $57.61^{\mathrm{Aa}}$ & $52.78^{\mathrm{Aa}}$ & $48.14^{\mathrm{Aa}}$ & $46.12^{\mathrm{Aa}}$ & $51.16^{\mathrm{A}}$ \\
\hline Mean & $58.76^{\mathrm{a}}$ & $49.68^{b}$ & $42.86^{\mathrm{c}}$ & $40.50^{c}$ & \\
\hline
\end{tabular}

Coefficient of Variation $(\mathrm{CV})=5.14 \%$; Capital letters followed by the same letter in the column do not differ (P > 0.05) by Tukey test. Tiny letters followed by the same letter in the line do not differ $(\mathrm{P}>0.05)$ by Tukey test.

height of residue had controlled the elongation of stems, presenting a similar condition to that found by [19] when comparing two cutting heights $(25 \mathrm{~cm}$ and $50 \mathrm{~cm})$ under different grazing intensities. This author observed that the greater intensity of defoliation $(25 \mathrm{~cm})$ controlled the stretching of stems, suggesting a greater renewal of tissues under more severe cutting conditions.

The mean percentage of stems changed with the evaluation periods (Table 4). Higher values $(\mathrm{P}<0.05)$ occurred in the first period of evaluation. Thus, it was observed the opposite effect to the one presented by the leaf blade fraction. There was no interaction $(\mathrm{P}>0.05)$ between cutting height of residues and evaluation period. According to [20], the stem elongation constitutes a characteristic process in clump grasses, which acts by increasing total dry matter yield either by improving the distribution of the available radiation throughout the canopy, or due to its highest level of DM in older ages. The same authors reported that the process of stems elongation is favored by the attenuation of light inside the canopy as it grows, thus reducing the quality of forage produced.

The stem fractions responded of linear positive form for all evaluated heights ( $\mathrm{Y}$ mean $=0.0053 \mathrm{x}+0.2556$; $\mathrm{R}^{2}=97.92 \%$ ). This behavior can be explained by the increase of support structures (stems), which vary in direct proportion to the necessary force to support the leaves [21]. According to [22], the stem fraction in tropical grasses, which is important for growth, can interfere in the canopy structure and in processes of competition for light.

The fraction of dead material showed no significant difference $(P>0.05)$ for the interaction height of residues $\mathrm{x}$ periods of the year and the averages. This effect was similar to that found by [15] with Tanzania grass (Panicum maximum Jacq.) under different heights of pasture management. The values for percentage of dead material are shown in Table 6.

No effect $(\mathrm{P}>0.05)$ was observed in the regression analysis of the dead material fraction as a function of residue heights, with an average value of $13.2 \%$. Despite the increase in total dry matter production, the shading effect caused by the growth of Mulato grass equalized the percentage of dead material. According to [23], reducing the accumulation of dead tissue due to shading, or even if there is no change, seems to be associated to a slow speed of development of plants grown under low light conditions, and also under a shaded microclimate where cool temperatures prevail, the relative humidity is slightly higher and there is a high moisture content in the soil.

There was no difference $(\mathrm{P}>0.05)$ for the interaction height of residue $\times$ evaluation periods on the leaf blade/stem ratio (Table 7). However, it was observed an increase $(\mathrm{P}<0.05)$ in the mean values of the leaf blade/stem ratios in relation to the periods of evaluation. The first evaluated period showed lower average than the other periods.

In agreement with the results for percentage of stems (Table 4), the leaf/stem ration as a function of the residue height presented a negative quadratic effect to the mean $(\mathrm{P}<0.01)$, according to the equation $\mathrm{Y}$ mean $=$ $0.0014 x^{2}-0.1121 x+3.105\left(R^{2}=99.72 \%\right)$. Therefore, the increase in the height of residue caused a decrease in the leaf blade/stem ratio in response to the concomitant increase in the stem fraction. According to [24], in shorter intervals between cuts the pasture shows a higher blade/stem ratio. This higher proportion of leaves can be attributed to the shorter length of the stems under shorter intervals between cuts. The observed decrease in the leaf/stem ratios is explained by the increased length of the stems when increasing cutting intervals. Additionally, [21] reported that the largest leaf areas recorded in tillers from higher pastures are a direct consequence of the 
Table 6. Percentages of dead material in pastures of Brachiaria hibrida cv. Mulato I under four cutting heights.

\begin{tabular}{|c|c|c|c|c|c|}
\hline \multirow{2}{*}{ Periods ofevaluation } & \multicolumn{4}{|c|}{ Heights of Residues (cm) } & \multirow{2}{*}{ Mean } \\
\hline & 10 & 20 & 30 & 40 & \\
\hline Jan-Mar & 11.42 & 16.00 & 18.60 & 13.43 & 14.86 \\
\hline Apr-Jun & 14.50 & 11.63 & 15.22 & 12.06 & 13.35 \\
\hline Jul-Sep & 9.34 & 12.26 & 15.50 & 17.15 & 13.56 \\
\hline Oct-Dec & 9.88 & 11.00 & 13.42 & 9.75 & 11.01 \\
\hline Mean & 11.30 & 12.72 & 15.69 & 13.10 & \\
\hline
\end{tabular}

Coefficient of Variation $(C V)=5.65 \%$; Capital letters followed by the same letter in the column do not differ $(\mathrm{P}>0.05)$ by Tukey test. Tiny letters followed by the same letter in the line do not differ $(\mathrm{P}>0.05)$ by Tukey test.

Table 7. Leaf blade/stem ratios in pastures of Brachiaria hibrida cv. Mulato I under four cutting heights.

\begin{tabular}{|c|c|c|c|c|c|}
\hline \multirow{2}{*}{ Periods of evaluation } & \multicolumn{4}{|c|}{ Heights of Residues (cm) } & \multirow{2}{*}{ Mean } \\
\hline & 10 & 20 & 30 & 40 & \\
\hline Jan-Mar & 1.80 & 0.86 & 0.77 & 0.66 & 1.02 \\
\hline Apr-Jun & 2.19 & 1.45 & 1.00 & 0.89 & 1.38 \\
\hline Jul-Sep & 2.73 & 1.79 & 1.28 & 1.10 & 1.73 \\
\hline Oct-Dec & 1.86 & 1.52 & 1.27 & 1.05 & 1.43 \\
\hline Mean & 2.14 & 1.41 & 1.08 & $0.93^{\mathrm{c}}$ & \\
\hline
\end{tabular}

Coefficient of Variation $(C V)=21.06 \%$; Capital letters followed by the same letter in the column do not differ $(P>0.05)$ by Tukey test. Tiny letters followed by the same letter in the line do not differ $(\mathrm{P}>0.05)$ by Tukey test.

imposed limits for this characteristic, i.e., the length of leaves had to adapt to reductions in canopy height by "shortening" their leaf blades.

During the first evaluation period it was observed higher number of leaves per tiller $(\mathrm{P}<0.05)$ (Table 8), with no difference $(\mathrm{P}>0.05)$ among the remaining time periods and the interaction height of residues $\mathrm{x}$ period of evaluation on the total number of leaves per tiller. In this study, the average number of total leaves in the first evaluation period was influenced by the rainy season in the region, despite the use of irrigation in the remaining periods.

It was observed a positive linear effect, described by the equation $Y$ mean $=0474 x+3.365\left(R^{2}=95.06 \%\right)$ for mean number of total leaves per tiller as a function the height of residue after cutting. According to [25], the number of leaves in a tiller is an important reference to the tillering potential because each axillary bud, associated to a generated leaf blade, can potentially generate a new tiller, and therefore can change the structural characteristics of forage.

In spite of differences in magnitude, the number of live leaves did not vary $(P>0.05)$ among the evaluation periods (Table 9). There was also no significant effect of the interaction height of residue $\mathrm{x}$ evaluation period on the number of live leaves. [26], in a study with Brachiaria decumbens, also found no effect of the average height on the number of live leaves per tiller. According to the authors, these results may be due to the fact that the number of leaves per tiller is genetically determined.

The evaluation on the number of green leaves per tiller as a function of the height of residues showed a linear positive effect $(P<0.01)$, as defined by the equation $Y$ mean $=0.0384 x+3.205\left(R^{2}=96.64 \%\right)$. [27] found a linear increase in the number of green leaves with increasing cutting heights $(5,10$ and $20 \mathrm{~cm})$. The authors also stated that the use of nitrogen fertilizer can simultaneously increase the total number of sheets, as well as the number of green leaves.

The mechanism of nitrogen action in prolonging the life of the sheet may be associated with the maintenance of a higher photosynthetic capacity for longer periods, without significant internal mobilization of $\mathrm{N}$ from older leaves. This behavior can be better understood if analyzed together with the process of leaves senescence [27]. Once established the senescence, much of the $\mathrm{N}$ is remobilized to the younger leaves and this mobilization can significantly contribute to the reduction of photosynthetic activity of older leaves [28].

The use of higher residual heights $(40 \mathrm{~cm})$ increased the average size of the leaf in $45 \%$ as compared to the lowest residues $(10 \mathrm{~cm})$ (Table 10). It was observed a higher $(\mathrm{P}<0.05)$ average length of the leaves in the first period, with no difference among the other periods. 
Table 8. Total number of leafs per tiller in pastures of Brachiaria hibrida cv. Mulato I under four cutting heights.

\begin{tabular}{cccccc}
\hline \multirow{2}{*}{ Periods of evaluation } & \multicolumn{2}{c}{ Heights of Residues (cm) } & Mean \\
\cline { 2 - 5 } Jan-Mar & 10 & 20 & 30 & 40 & 4.93 \\
Apr-Jun & 4.07 & 4.13 & 5.70 & 5.80 & 4.52 \\
Jul-Sep & 3.84 & 4.27 & 4.89 & 5.09 & 4.44 \\
Oct-Dec & 3.80 & 4.13 & 4.73 & 5.09 & 4.32 \\
Mean & 4.02 & 3.96 & 4.29 & 5.02 & \\
\hline
\end{tabular}

Coefficient of Variation $(\mathrm{CV})=8.81 \%$; Capital letters followed by the same letter in the column do not differ $(\mathrm{P}>0.05)$ by Tukey test. Tiny letters followed by the same letter in the line do not differ $(\mathrm{P}>0.05)$ by Tukey test.

Table 9. Number of live leaves per tiller in pastures of Brachiaria hibrida cv. Mulato I under four cutting heights.

\begin{tabular}{|c|c|c|c|c|c|}
\hline \multirow{2}{*}{ Periods of evaluation } & \multicolumn{4}{|c|}{ Heights of Residues (cm) } & \multirow{2}{*}{ Mean } \\
\hline & 10 & 20 & 30 & 40 & \\
\hline Jan-Mar & $3.77^{\mathrm{Ab}}$ & $3.53^{\mathrm{Ab}}$ & $4.40^{\mathrm{Aab}}$ & $4.80^{\text {Aa }}$ & $4.13^{\mathrm{A}}$ \\
\hline Apr-Jun & $3.44^{\mathrm{Ab}}$ & $4.13^{\mathrm{Aab}}$ & $4.60^{\mathrm{Aa}}$ & $4.82^{\mathrm{Aa}}$ & $4.25^{\mathrm{A}}$ \\
\hline Jul-Sep & $3.69^{\mathrm{Ab}}$ & $4.00^{\text {Aab }}$ & $4.44^{\mathrm{Aab}}$ & $4.71^{\text {Aa }}$ & $4.21^{\mathrm{A}}$ \\
\hline Oct-Dec & $3.78^{\mathrm{Aab}}$ & $3.71^{\mathrm{Ab}}$ & $4.07^{\mathrm{Aab}}$ & $4.76^{\mathrm{Aa}}$ & $4.08^{\mathrm{A}}$ \\
\hline Mean & $3.67^{\mathrm{c}}$ & $3.84^{\mathrm{c}}$ & $4.38^{\mathrm{b}}$ & $4.77^{\mathrm{a}}$ & \\
\hline
\end{tabular}

Coefficient de Variation $(\mathrm{CV})=8.06 \%$; Capital letters followed by the same letter in the column do not differ $(\mathrm{P}>0.05)$ by Tukey test. Tiny letters followed by the same letter in the line do not differ $(\mathrm{P}>0.05)$ by Tukey test.

Table 10. Average size of leaves (cm) in pastures of Brachiaria hibrida cv. Mulato I under four cutting heights.

\begin{tabular}{|c|c|c|c|c|c|}
\hline \multirow{2}{*}{ Periods of evaluation } & \multicolumn{4}{|c|}{ Heights of Residues (cm) } & \multirow{2}{*}{ Mean } \\
\hline & 10 & 20 & 30 & 40 & \\
\hline Jan-Mar & $12.96^{\mathrm{Ac}}$ & $19.44^{\mathrm{Ab}}$ & $20.32^{\mathrm{Ab}}$ & $25.94^{\mathrm{Aa}}$ & $19.66^{\mathrm{A}}$ \\
\hline Apr-Jun & $12.25^{\mathrm{Ac}}$ & $15.27^{\mathrm{ABbc}}$ & $17.04^{\text {Aab }}$ & $21.07^{\mathrm{ABa}}$ & $16.41^{\mathrm{B}}$ \\
\hline Jul-Sep & $12.36^{\mathrm{Ab}}$ & $15.80^{\text {ABab }}$ & $16.99^{\mathrm{Aab}}$ & $20.47^{\text {Вa }}$ & $16.40^{\mathrm{B}}$ \\
\hline Oct-Dec & $9.82^{\mathrm{Ac}}$ & $13.50^{\mathrm{Bbc}}$ & $17.03^{\text {Aab }}$ & $18.91^{\mathrm{Ba}}$ & $14.81^{\mathrm{B}}$ \\
\hline Mean & $11.85^{\mathrm{d}}$ & $16.00^{c}$ & $17.84^{\mathrm{b}}$ & $21.60^{\mathrm{a}}$ & \\
\hline
\end{tabular}

Coefficient of Variation $(\mathrm{CV})=9.77 \%$; Capital letters followed by the same letter in the column do not differ $(\mathrm{P}>0.05)$ by Tukey test. Tiny letters followed by the same letter in the line do not differ $(\mathrm{P}>0.05)$ by Tukey test.

The heights of residues showed a linear increasing effect on the average size of the leaves, according to the equation Y mean $=3.1095 x+90.48\left(R^{2}=98.11 \%\right)$. Thus, along with the stem fractions, this variable can be used to justify the total dry matter production in the highest cutting heights. These results are inferior to those found by [29] with Marandu grass at cutting heights of $10 \mathrm{~cm}$ and $20 \mathrm{~cm}$, in which were found $21.44 \mathrm{~cm}$ and $25.51 \mathrm{~cm}$, respectively. Also according to these authors, the longest leaf blades in higher cuts reflect the greater part to be covered by the sheet until it is expanded. [30] reported that the decreased length of the blade constitutes an effective way to reduce the leaf length.

The values obtained for tiller density (Table 11$)$ showed no differences $(\mathrm{P}>0.05)$ among the evaluation periods and for the interaction height of residue $\mathrm{x}$ evaluation periods. However, it was observed a tendency to decrease the number of tillers in treatments with fewer residues (10 to $20 \mathrm{~cm}$ cutting heights) when compared with the highest cutting treatment.

Similar values to those found in this study were reported by [29] in their work with Brachiaria brizantha, which were 651.22 and 747.52 tillers $/ \mathrm{m}^{2}$ to 10 and $20 \mathrm{~cm}$ cutting heights, respectively. Also in the present study were not found differences $(\mathrm{P}>0.05)$ in tillering among the studied heights of residues. To [31], defoliation influences tiller density, so that when the cuts are frequent there is a reduction in forage production in relation to less frequently defoliated plants, being tiller production more affected than the number of tillers per soil area. 
Table 11. Tiller density (tillers $/ \mathrm{m}^{2}$ ) in pastures of Brachiaria hibrida cv. Mulato I under four cutting heights.

\begin{tabular}{cccccc}
\hline \multirow{2}{*}{ Periods of evaluation } & \multicolumn{4}{c}{ Heights of Residues (cm) } & Mean \\
\cline { 2 - 5 } & 10 & 20 & 30 & 40 & 594.33 \\
Jan-Mar & 669.33 & 570.00 & 517.00 & 621.00 & 645.44 \\
Apr-Jun & 666.66 & 659.56 & 524.22 & 731.33 & 598.00 \\
Jul-Sep & 612.22 & 516.45 & 546.00 & 717.33 & 603.50 \\
Oct-Dec & 601.11 & 452.22 & 620.89 & 739.78 & 702.36 \\
Mean & 637.33 & 549.56 & 552.03 & & \\
\hline
\end{tabular}

Coefficient of Variation $(\mathrm{CV})=12.90 \%$; Capital letters followed by the same letter in the column do not differ $(\mathrm{P}>0.05)$ by Tukey test. Tiny letters followed by the same letter in the line do not differ $(\mathrm{P}>0.05)$ by Tukey test.

The results indicate the need of studying the structural characteristics together with the qualitative characteristics for a better understanding of this forage management.

\section{Conclusion}

The use of cutting at $10 \mathrm{~cm}$ causes a reduction in the total dry matter production of Mulato grass I. Cutting heights between 20 and $30 \mathrm{~cm}$ contributes positively to increasing the total number of leaves, the number of green leaves, the average size of the leaf blade and the total dry matter production. Cuttings near $40 \mathrm{~cm}$ are not recommended because they are responsible for the decrease in leaf/stem ratio and for the increasing in stem fractions and dry matter content, thus affecting the structure of the canopy.

\section{References}

[1] Linhares, C.D.M.S. and Souza Junior, J.B.F.D. (2008) Alternative Food Sources for Ruminants. Pubvet, $2,303$.

[2] Bitencourt Junior, D., Siewerdt, L. and Ferreira, O.G.L. (2008) Produtive Potential and Morphological Characteristics of Mulato Grass under Defered Grow in the Summer. Brazilian Journal of Agroscience, 14, 68-76.

[3] Chapman, D.F. and Lemaire, G. (1993) Morphogenic and Structural Determinants of Plant Regrowth after Defoliation. In: Baker, M.J., Ed., Grasslands for Our World, SIR, Wellington, 55-64.

[4] Carvalho, P.F.C., Ribeiro Filho, H.M.N., Poli, C.H.E.C., Moraes, A. and Delagarde, R. (2001) The Importance Pasture structure on Intake and Diet Selection of Grazing Animals. Proceedings of the Annual Meeting of the Brazilian Society of Animal Science, Piracicaba, 23-26 July 2001, 853-871.

[5] Paciullo, D.S.C., Deresz, F., Aroeira, L.J.M., Morenz, M.J.F. and Verneque, R.D.S. (2003) Morphogenesis and Morphogenesis and Accumulation of Leaf Biomass of Elephant Grass in Different Seasons. Brazilian Agriculture Research, 38, 881-887.

[6] Vieira, M.M.M. and Mochel Filho, W.J.E. (2010) Influence of Abiotic Factors on the Flow of Biomass and Canopy Structure. Animal Science Archives, 59, 15-24.

[7] Embrapa (2006) Brazilian System of Soil Classification. Embrapa Press, Rio de Janeiro.

[8] Mari, L.J. (2003) Interval between Cuts of Marandugrass (Brachiaria brizantha Stapfcv Marandu.): Production, Nutritive Value and Losses Associated with the Fermentation of the Silage. M.Sc. Thesis, University of São Paulo, Piracicaba.

[9] Uebele, M.C. (2002) Demographic Patterns of Tillering and Production of Forage in Mombaça Grass Undergoing Intermitante Stocking Regimes. M.Sc Thesis, University of São Paulo, São Paulo.

[10] Mistura, C., Fonseca, D.M.D. Moreira, L.D.M., Fagundes, J.L., Morais, R.V., Queiroz, A.C.D. and Ribeiro Junior, J.I. (2007) Effect of Nitrogen Fertilization and Irrigation on the Chemical Composition of Leaf Blades and Whole Plant of Elephant Grass under Grazing. Brazilian Journal of Animal Science, 36, 1707-1714.

[11] Ferreira, G.D.G., Santos, M.V.F., Lira, M.A., Melo, A.C., Almeida, O.C., Ribeiro, C.R., Oliveira, R.L. and Palmieri, A.D. (2013) Quantitative and Qualitative Characteristics of Elephant Grass. Colombian Journal of Livestock Sciences, 105, 15-23.

[12] Souza, C.G.D., Santos, M.V.F.D., Silva, M.D.C., Cunha, M.V.D. and Lira, M.D.A. (2006) Qualitative Measures of Panicum maximumjacq. Varieties Subjected to Nitrogen Fertilization. Caatinga Journal, 19, 333-338.

[13] Gomide, J.A. (1997) Morphogenesis and Growth Analysis of Tropical Grasses. Proceedings of 1st International Symposium on Animal Production Under Grazing, Viçosa, 13-16 September 1997, 411-429. 
[14] Canto, M.W., Cecato, U., Almeida Junior, J., Jobim, C.C., Agulhon, R.A., Gai, V.F., Hoeschl, A.R. and Queiroz, M.F.S. (2002) Winter Animal Production in Summer Deferred Tanzania Grass and Managed under Different Heights. Brazilian Journal of Animal Science, 31, 1624-1633.

[15] Canto, M.W., Jobim, C.C., Gasparino, E. and Hoeschl, A.R. (2008) Characteristics of Pasture and Forage Accumulation in Tanzaniagrass Subjected to Different Management Heights. Brazilian Agricultural Research, 43, 429-435.

[16] Carnevalli, R.A., Silva, S.C.D., Bueno, A.A.O., Uebele, M.C., Bueno, F.O., Silva, G.N. and Moraes, J.P. (2006) Herbage Production and Grazing Losses in Panicum maximum cv. Mombaça under Four Grazing Managements. Tropical Grasslands, 40, 165-176.

[17] Hack, E.C., Bona Filho, A., Moraes, A., Carvalho, P.C.F., Martinichen, D. and Pereira, T.N. (2007) Structural Characteristics and Milk Production in Mombaça Grass (Panicum maximumJacq.) Pasture Subjected to Different Grazing Heights. Rural Science, 37, 218-222. http://dx.doi.org/10.1590/S0103-84782007000100035

[18] Cecato, U., Machado, A.O., Martins, E.N., Pereira, L.A., Barbosa, M.A.A.F. and Santos, G.T.D. (2000) Evaluation of Production and Regrowth Characteristics of Cultivars and Accessions of Panicum maximumJacq. under Two Cutting Heights. Brazilian Journal of Animal Science, 29, 660-668.

[19] Pena, K.S. (2007) Morphogenesis, Structural and Herbage Accumulation Characteristics of Tanzania Grass Subjected to Intensities and Frequencies of Cutting. M.Sc. Thesis, Federal University of Viçosa, Viçosa.

[20] Cândido, M.J.D., Silva, R.G.D., Neiva, J.N.M., Facó, O., Benevides, Y.I. and Farias, S.F. (2006) Biomass Flow in Tanzania Grass Grazed by Sheep under Three Rest Periods. Brazilian Journal of Animal Science, 35, 2234-2242.

[21] Sbrissia, A.F. and Silva, D.S. (2008) Compensation of Size/Population Dendidade of Tillers in Marandu Grass Pastures. Brazilian Journal of Animal Science, 37, 35-47.

[22] Fagundes, J.L., Fonseca, D.M.D, Morais, R.V.D., Mistura, C., Vitor, C.M.T., Gomide, J.A., Nascimento Junior, D., Santos, M.E.R. and Lambertucci, D.M. (2006) Evaluation of Structural Characteristics of Brachiaria Grass in Pastures Fertilized with Nitrgênio in Four Seasons. Brazilian Journal of Animal Science, 35, 30-37.

[23] Castro, C.R.T.D, Garcia, R., Carvalho, M.M. and Couto, L. (1999) Forage Production of Grasses Grown under Low Light Conditions. Brazilian Journal of Animal Science, 28, 919-927.

[24] Maranhão, C.D.M.A. (2008) Productive, Morphogenetic and Structural Characteristics of Signal Grass Subjected to Cutting Intervals and Nitrogen Fertilization. M.Sc. Thesis, Southwest State University of Bahia, Jequié.

[25] Nascimento Junior, D., Barbosa, R.A. and Andrade, C.M.S. (2002) Fundamentals of Pasture Management: Evolution and Current Status. Proceedings of 1st Symphosium on Strategic Pasture Management, Viçosa, 25-27 June 2002, 149196.

[26] Santos, M.E.R., Fonseca, D.M.D., Gomes, V.N., Silva, S.P.D. and Santos, A.L. (2010) Characterization of Tillers in Pasture of Brachiaria decumbens under Continuous Stocking. Biosphere Encyclopedia, 6, 1-9.

[27] GarcezNeto, A.F., Nascimento Júnior, D., Regazzi, A.J., Fonseca, D.M., Mosquim, P.P. and Gobbi, K.F. (2002) Morphogenetic and Structural Responses of Panicum maximum cv. Nives Mombasa under Different Nitrogen Fertilization Levels and Cutting Heights. Brazilian Journal of Animal Science, 31, 1890-1900.

[28] Oliveira, A.B., Pires, A.J.V., Matos Neto, U., Carvalho, G.P., Veloso, C.M. and Silva, F.F. (2007) Morphogenesis of Tanzania Grass Subjected to Different Fertilization Levels and Cutting Intensities. Brazilian Journal of Animal Science, 36, 1006-1013.

[29] Marcelino, K.R.A., Nascimento, D., Silva, S.C., Euclides, V.P.B. and Fonseca, D.M. (2006) Morphogenetic and Structural Characteristics and Forage Production of Marandu Grass Subjected to Intensities and Frequencies of Defoliation. Brazilian Journal of Animal Science, 35, 2243-2252.

[30] Duru, M. and Ducrocq, H. (2000) Growht and Senescence of the Successive Leaves on a Cocksfoot Tiller. Effect of nitrogen and cutting regime. Annals of Botany, 85, 645-653. http://dx.doi.org/10.1006/anbo.1999.1117

[31] Volenec, J.J. and Nelson, C.J. (1983) Responses of Tall fescue Leaf Meristems to N fertilization and Harvest Frequency. Crop Science, 23, 720-724. http://dx.doi.org/10.2135/cropsci1983.0011183X002300040028x 